\title{
カーエレクトロニクス実装の現状と展望
}

\section{Present Condition and Perspective of In-Vihcle Electronics Packaging}

$$
\text { カーエレクトロニクス研究会 }
$$

\section{1.はじめに}

近年, 自動車の電子制御は, 自動運転につながる予防安 全の分野と, 電気自動車につながる制御の電動化と大きく

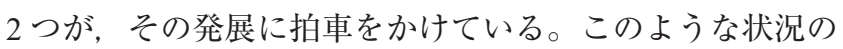
中, 今年は電動化をキーワードにまとめた。

$\mathrm{EV}^{\dagger} \cdot \mathrm{FCV}^{\dagger} \cdot \mathrm{HV}^{\dagger}$ と実装, この分野の高密度実装, プ リント配線板間・プリント配線板ーデバイス間の接続, 半 導体実装技術の順に現状と展望を解説する。

最後に, 当研究会として継続的に活動している実車テア ダウン活動を紹介する。

$$
\text { 文責・大竹精一郎 /デンソー }
$$

\section{EV・FCV・HV と実装技術}

ゼロエミッションに向けて自動車の動力が内燃機関から モータへ移行しようとしており, パワートレインシステム の電動化が進んでいる。電動システムを構成する機器とし ては, インバータ, DC-DCコンバータなどがあり, 実装 技術においては, より大電流, 高放熱, 高絶縁, 高耐熱が 求められるようになってきている（図 1)。

$\mathrm{EV} \cdot \mathrm{HV}$ 向けインバータの $\mathrm{IGBT}^{\dagger}$ モジュールなどのパ ワー半導体には小型・高出力化が求められ, 2020 年には
$1,000 \mathrm{kVA} / \mathrm{L}$ を超える出力密度が要求されると予測されてい る ${ }^{1)}$ 。放熱性能を確保するために, 間接冷却から直接冷却 へ，また，片面冷却から両面冷却へと放熱構造が変化して きている ${ }^{1)}$ 。また，小型化・大電流化を達成するために, チップ接続構造が太線ワイヤからリボンワイヤ・リードフ レーム接続に変わってきている ${ }^{1)}$

次に HV 向け IGBT モジュールにおけるリードフレーム とチップとの接合事例として，両面はんだ接合構造のパッ ケージについて述べる。はんだ接続部には $0.4 \mathrm{kA} / \mathrm{cm}^{2}$ ほど の電流が流れ, 特に 2 in 1 パッケージの内部配線にジョイン 卜を持つ場合, ジョイント部のはんだに流れる電流密度が チップ接合部の 5〜10 倍になり，エレクトロマイグレー ションを発生させない界面の設計が重要になる ${ }^{2)}$ 。

最後にFCVについて述べる。FCV を構成する電動シス テム用機器は, インバータを含むパワーコントロールユ ニット，モータ，駆動用バッテリーであり，ほほ HV 技術 と同じとなる ${ }^{3)}$ 。 FCV 特有の技術は, フューエルセルス タック，および高圧水素タンクであり，フューエルセルの 設計においては, 車両停止時のセル内の水分を適切にコン トロールすることで低温始動性を確保する必要がある ${ }^{3)} 。$ 文責・三宅敏広／デンソー

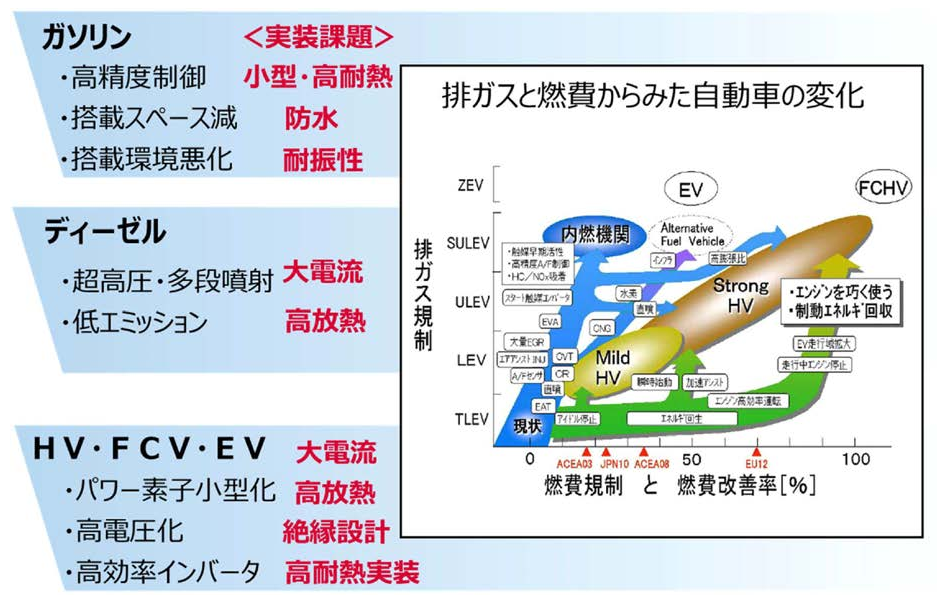

図 1.パワートレイン制御の動向と実装技術 


\section{3. 高密度実装}

乗用車 1 台に搭載される電子制御装置 $\left(\mathrm{ECU}^{\dagger}\right)$ 数は増加

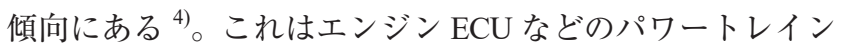
系 ECU に加えて, ナビゲーションシステムなどの情報系 $\mathrm{ECU}$, ステレオカメラモジュールや $\mathrm{ADAS}^{\dagger}$ などの走行安 全系 ECUなどの高機能システムの搭載数が増加したことに よる。乗用車への ECU 搭載場所は限られるため, ECUの 小型・高密度化は重要課題の一つとなっている5)。

ECU の小型・高密度化に向けて, 0.8 mm ピッチ BGA 部 品や QFN 部品などが搭載可能なプリント配線板が開発され ている6。 面積当たりの発熱量が増加するため, ECUの高放熱化が重 要となる。ECU 高放熱化のために, 厚銅配線を内外層に配 置した銅コア基板や銅ベース基板に加え，局所的に銅を埋 め达むプリント配線板なども開発・製品化されている ${ }^{7), 8}$ 。

一方, 欧米や中国などでの $\mathrm{CO}_{2}$ などの削減を義務づけた 環境規制に対応するため, 各自動車メーカはガソリンエン ジンなどの内燃機関の省燃費化に加え, $\mathrm{HEV}^{\dagger}$ や EV, FCV など駆動部を電動化した環境対応自動車を開発・製品化し ている。環境対応自動車のキー技術の一つが, インバータ に代表されるパワーエレクトロニクスである。インバータ には, 車両搭載性を重視した小型・高密度化, 航続距離を 延ばす高効率化, 快適な加速性能を実現する高出力化, 厳 しい車載環境下での高信頼化などが求められる。

インバータの主要部品である, パワーモジュールの一例 を図 2 に示す 9),10)。パワーモジュールは, IGBT とダイオー ド, 絶縁基板, はんだ, 放熱板などから構成される。従来 の放熱材を介して冷却する間接放熱構造から, パワーモ

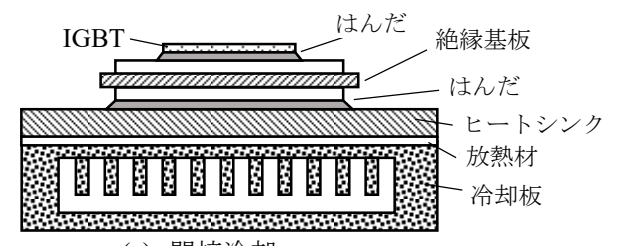

(a) 間接冷却

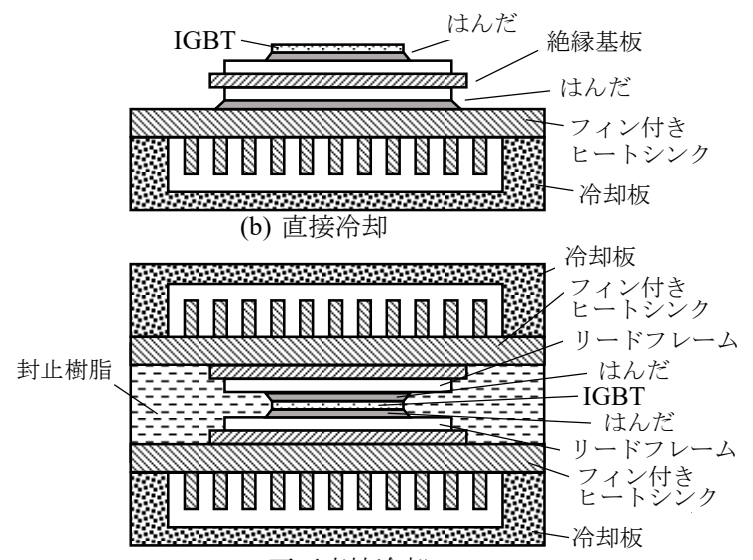

(c)両面直接冷却

図 2. パワーモジュールの一例
ジュール底面をフィン構造として冷却水に浸漬する直接水 冷構造への改良により, 放熱材部分の熱抵抗が低減し冷却 効率が 30\% 程度向上された。さらに, 放熱性向上のため, IGBT やダイオードの両面にリードフレームをはんだなどで 接合し，リードフレームは絶縁材を介して放熱板に接続さ れる, 両面直接水冷構造も開発・製品化されている 9) 13)。 また $\mathrm{Si}$ 半導体に比べて, 低損失・高効率化半導体である $\mathrm{SiC}$ や $\mathrm{GaN}$ なども開発・製品化されている ${ }^{14) ~ 17) 。 S i C ~ は ~}$ 環境温度が $175^{\circ} \mathrm{C}$ 超でも動作可能であり, 冷却装置を簡素 化できる。また $175^{\circ} \mathrm{C}$ 超の動作に向け, 高耐熱接合材とし て $\mathrm{Sn}-\mathrm{Sb}$ 系や $\mathrm{Sn}-\mathrm{Cu}$ 系, $\mathrm{Zn}-\mathrm{Al}$ 系の高耐熱はんだ材や，金 属粒子の粒径をナノメートルサイズにすることで，融点が バルク状態より低くなり焼結温度が大幅に低下できる $\mathrm{Ag}$, $\mathrm{Cu}$ や $\mathrm{Ni}$ などのナノ粒子焼結材や, 拡散接合材の研究開発 も行われている ${ }^{17) \sim 20) 。 ~}$

文責・河喜多心哉 /日立製作所

\section{4. プリント配線板間, プリント配線板ーデバイス間 の接続}

自動車用制御システムにおいて昨今，機電一体や自動運 転の開発が急速に進められている。

これらの内部におけるプリント配線板間やプリント配線 板ーデバイス間接続は，はんだ溶接接続，ケーブル配線接 続，コネク夕接続が考えられるが，それぞれ表 1 に示され るような長所, 短所がある。

自動車用制御システムはその制御構成により小型化，高

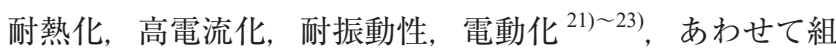
み立ての容易性などが求められ，その妥当性から上記 3 つ の接続手法のいずれかが選択される。

はんだ溶接接続はピンヘッダやバスバーを導線として接 続するが, 振動により発生する力がはんだ接続部にすべて かかりやすいため, 熱による物性低下も考慮に入れて破断 に対する信頼性を確認する必要がある。ケーブル配線接続 では終端部はコネクタ, 導線はケーブルであり, 終端コネ クタのはんだ接続部もケーブルも振動に対して強くなる が, ケーブル取り付けや取り回しが煩雑になりやすい。コ ネクタ接続では振動方向に対して可動する機能を設けるこ とにより振動時に発生する力を可動部に分担させることが できるので，はんだ接続部は振動に対して強くなるが，許 容以上の振動では可動部での金属疲労破断 ${ }^{24)}$ や, コネクタ 接点部の摺動による接触抵抗増大 ${ }^{25)}$ が発生する。

機器のアセンブリははんだ溶接接続かケーブル配線接続 が多かったが，昨今では小型化，および組み立ての容易性

表 1. 接続方法の長所, 短所一覧

\begin{tabular}{l|c|c|c|c}
\hline \multicolumn{1}{c|}{ 接続方法 } & 小型化 & はんだ部振動対策 & アセンブリ & リワーク \\
\hline はんだ溶接 & $\bigcirc$ & $\times$ & $\triangle$ & $\times$ \\
\hline ケーブル配線 & $\times$ & $\bigcirc$ & $\triangle$ & $\triangle$ \\
\hline コネクタ & $\bigcirc$ & $\bigcirc$ & $\bigcirc$ & $\bigcirc$ \\
\hline
\end{tabular}



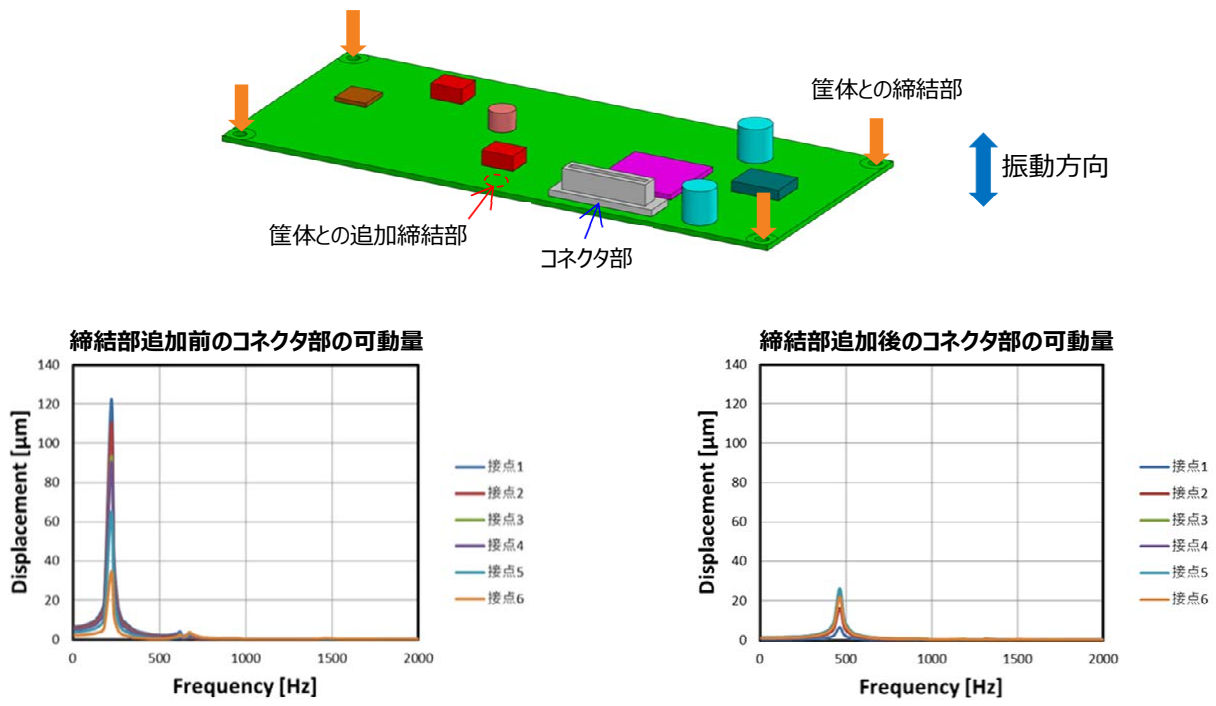

図 3. 可動量低減の簡単な例

から, 大電流接続も含めてコネク夕接続が増えつつある。 コネクタ接続の場合, 上述の通り, 許容を超えた振動では 可動部での金属疲労破断や, コネク夕接点部での摺動が発 生する。これらを避けるには, 機器の設計段階において, 固有值解析, 周波数応答解析を実施して可動量を許容以下 に低減する必要がある（図 3）。低減するには質量は軽く, 剛性, 減衰は高くが基本となるが, 質量, 減衰は大きく変 えられないことが多いので，質量配置の見直し，剛性を高 くする（筐体との固定を増やす）などが主となる。振動条 件は正弦波振動のみでなく，ランダム振動も想定し ${ }^{26), 27)}$, 熱による影響も加味して判断する必要がある。

文責・三田夏大／イリソ電子工業

\section{5. 車載特有の半導体実装技術 ${ }^{28}$}

近年, 自動車を取り巻く環境は, 燃費向上や排ガス削減 などの地球環境問題に加え，事故撲滅のための自動運転へ の期待が急速に高まりつつある。

\section{1 車の電動化と半導体製品}

地球環境問題には, 電動化が牵引し, 図 4 のような構成 の各種車載システムが今まさに電動化されている。このよ うなシステムでは, Sensor は高精度化・高信頼性化で半導 体センサが主流となっている。Controller は, 当然半導体集 積化回路で構成され，Actuator は，デジタル制御される。 このように車の電動化は, 半導体製品と共に成長してきた。

\section{2 車載特有の半導体実装技術の現状}

車載環境は, 振動, 温度, 電気ノイズなどの環境が厳し い。半導体民生技術をそのまま車載用には適用できないた め, 民生技術をブラッシュアップさせて，車載用に適用さ せてきている。

この事例として， $\mathrm{Cu}$ ワイヤについて説明する。 $\mathrm{Au}$ の高 騰より, 半導体の電気信号の取出線は $\mathrm{Au}$ ワイヤから $\mathrm{Cu}$ ワ イヤへの切り替えが, 民生で約 10 年前から始まり, 現在で

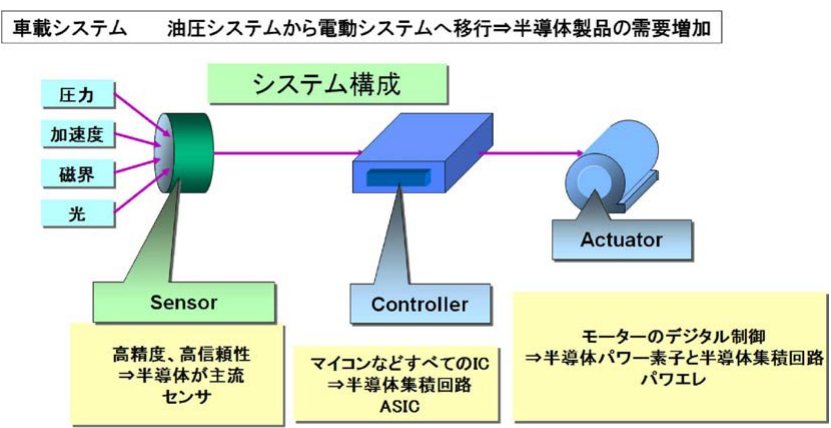

車載システムにおける電子化は、半導体製品が支える

図 4. 車載システムにおける半導体製品の役割 ${ }^{28}$

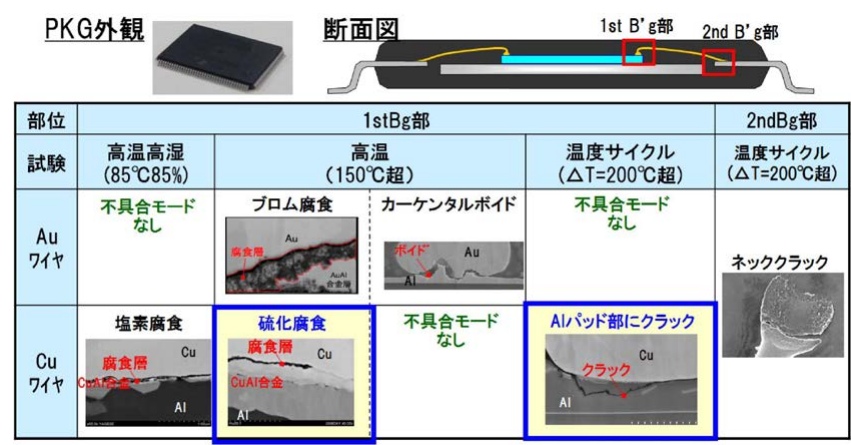

図 5.Cu ワイヤの不具合モードまとめ ${ }^{29,30)}$

は主流になりつつある。例えば, 図 5 のように, $\mathrm{Cu}$ ワイヤ の接続部は，高温高湿化で接合部で腐食することが知られ ていたが，車載では，温度が民生より高くなることによ り，高温だけでも腐食する現象が新たに発見された。その ためにいろいろな工夫が必要になり 299,30), その対応など で，約 10 年遅れて車載用に採用されているのが現状であ る。 


\section{3 展望}

今後は, 車の電動化に加え, 自動運転の技術レベルが, ここ数年で急速に向上していくと予測され, 車載用半導体 製品においては, 今まで以上に高速化と大容量化が求めら れる。そのようなニーズに対応する車載用半導体実装技術 は, 民生技術発展速度と同じ速さで進まなくてはいけな い。この時代に対応するため, 各社の模索が始まっている。 文責・大竹精一郎 /デンソー

\section{6. 研究会活動として実車をテアダウン}

当研究会では, 車載システムの動向と必要な実装技術と して, システム化 (ECU 統合) /電動化 $(\mathrm{X}$ by wire $) /$ 電子 化・無線化 (X by wireless) などをテーマとして取り組んで いる。しかし実際の車でセンサー〜ハーネス〜 ECU〜アク チュエータがどのように取り付けられているか知る機会は 少ない。そこで廃車を解体してエレクトロニクス制御機器 の搭載状態や機器の実装状態を調査するテアダウン活動を 進めている。

\section{1 テアダウン実施}

2016 年 5 月 27 (金) 28（土）東京都江戸川区某所にお いて, カーエレクトロニクス研究会のメンバー 9 人が自前 の工具を持ち寄って集まった。テアダウンする車種は日産 シーマ(図6)。

できるだけ多くのセンサーや電子機器が付いているであ ろうと期待した車種選定である。まずは安全のために指差 呼称を行い, 事前に下調べした手順に沿って, 複数のチー ムに分かれて解体を始めた。ボンネットを取り外し, エン ジンカバーを外し, センサーやアクチュエー夕類があると 思われる箇所に向かって部品を外していく（図 7)。別の チームは, 車内のシートを外し, ドア周りの部品を取り外 し, 一番難易度の高いハンドル・メーターパネル・ダッ シュボード付近を解体していく。さらに後方では, トラン クカバーを取り外し, トランク内の ECUやハーネスを取り 外していく。今回のテアダウンのコンセプトは, セン サー〜ハーネス〜 ECU〜アクチュエータがどのように接続 されているかを知ることなので, 取り外し前後の動画や写 真を撮ることも重視した。

当日はあいにくの小雨であったにも関わらず, メンバー は時間を忘れて解体を続け, 多くのセンサー類, ECU, ア クチュエータを取り外すことができた。しかしエンジン ルームと室内をつなぐハーネスは難易度が高く取り外すこ とが困難であったため，プロに依頼してエンジン，ミッ ション, マフラー, ガソリンタンクなどを外してもらい, 初日の作業は終了。翌日はハーネスを丁寧に取り外し, 実 際の配置状態を再現するように並べていく（図 8)。

\section{2 電子機器の観察}

取り外した電子機器はそれぞれ分担して観察した。エン ジン $\mathrm{ECU}, \mathrm{ABS}^{\dagger}$, ブレーキ $\mathrm{ECU}$, ナビ, DVD, オーディ
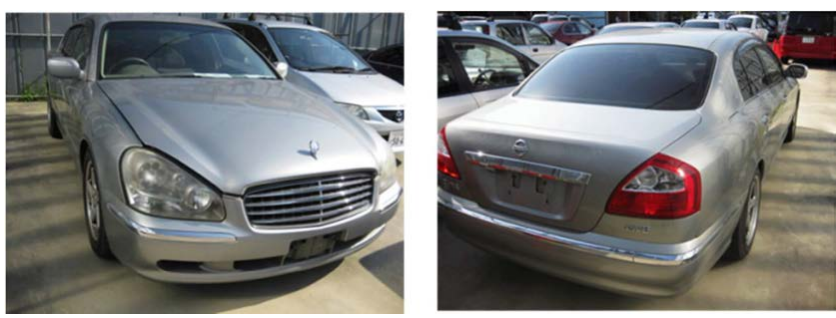

図 6. テアダウン前の日産シーマ
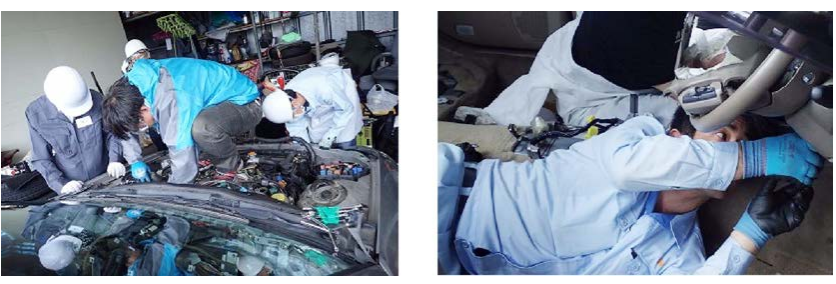

図 7. テアダウン作業中の様子
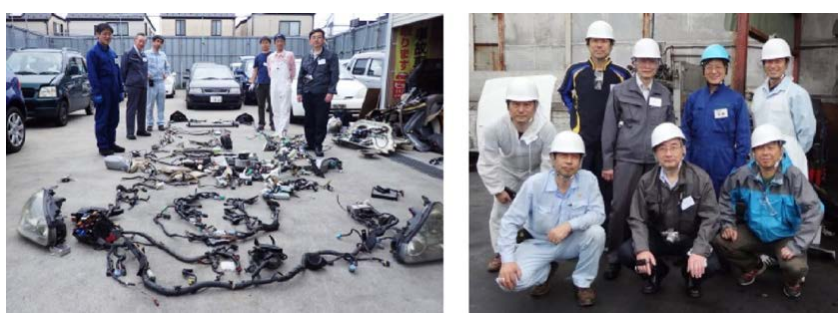

図 8. 取り外した電子機器とハーネス

オ，オーデイオ ECU，エアバッグ，エアコン， $\mathrm{ETC}^{\dagger}$, メー ター, ハーネスなどである。尚テアダウンの概要報告とし ては, 2016 年 11 月 30 (水) のカーエレクトロニクス公開 研究会で報告済みであるが，概要は以下である。

・実車解体という体験は, 非常に有意義であった

・多くの発見や驚きが得られた

- 寸法・重量測定, 外観観察, 基板仕様の調査, X 線に よる調査を行った（非破壊検査）

・基板やはんだ接合部の劣化部を解析しようと考えてい たが, 劣化がみられなかった

・ 15 年前という古い車種のため, システムが古かった

・詳細な目的を持ってテアダウン, 観察・比較分析しな いと明確な結果は得られない

\section{3 今後の取組み予定}

初回のテアダウンについては, 『まずは体験しよう』とい うことでスタートし，一定以上の知見を得ることができ た。今後はもっと深く知見を得ようと, 回路・実装設計技 術委員会の有識者に協力を仰ぐ予定である。解析の観点で は, 基板の破壊検査（断面研磨して基板内部の観察，はん だ接合部の観察）を行う予定である。尚今後のテアダウン の方向性としては, 旧型 vs 新型, 汎用車 vs 高級車, ガソ リン車 vs ハイブリッド車, 日本車 vs 外国車など比較分析 を行うことを考えており，1台／年のペースでテアダウン 
を継続する。次のテアダウンとしてはハイブリッド車を第

一候補として車種探しをしている。

尚, テアダウンを体験するにあたり多大なご尽力を頂い た有限会社実装彩科の齋藤和正様に感謝します。

文責・長谷川清久 /図研

(2017.10.24- 受理)

\section{文献}

1) 堀井良和：“車の電動化・知能化に向けた実装技術動向と課 題, ”エレクトロニクス実装学会カーエレクトロニクス研究 会公開研究会予稿集, pp. 21-32, 2017.7

2) 門口卓矢：“環境対応車向けパワーモジュールにおけるはん だ接合部の設計技術,”JIEP 最先端実装技術シンポジウム資 料, 2017.6

3) 大仲英巳 : “燃料電池自動車 (FCV) の開発状況と普及拡大に 向けた動向, ”エレクトロニクス実装学会カーエレクトロニ クス研究会公開研究会予稿集, pp. 47-82, 2016.11

4) 株式会社富士キメラ総研：“2014 車載 ECU 関連市場の現状 と将来展望,”2014

5) 株式会社富士キメラ総研：“車載ECUアナライジング\&マー ケットレポート 2012,”2011

6) 日本シイエムケイ株式会社ホームページ, http://www.cmkcorp.com/product/automotive/fineTH.html

7) 長楽公平，松井亜紀子：“銅コイン基板の放熱性検証,”第 30 回エレクトロニクス実装学会春季講演大会予稿集, pp. $460-463,2016$

8) 戸田光昭, 大関政広, 志々目和男：“放熱機能を有する車載 用プリント配線板の放熱特性評価, ”エレクトロニクス実装 学会誌, Vol. 19, No. 5, pp. 305-309, 2016

9) 奥村智巳, 坂本善次, 平野尚彦, 石井 隆, 赤川 隆: “両 面放熱パワーモジュールの実装構造,” Mate2009 予稿集, pp. 91-94, 2009. 1

10) 平野尚彦, 真光邦明, 奥村知巳 : “ハイブリッド自動車用イ ンバータ両面放熱パワーモジュール「パワーカード」, デ ンソーテクニカルレビュー, Vol. 16, 2011

11) 木村隆志, 齋藤隆一, 久保謙二, 中津欣也, 石川秀明, 佐々木 要：“ハイブリッド電気自動車向け高電力密度イン バータ,” 日立評論, Vol. 95, No. 11, pp. 42-47, 2013 年 11 月

12) 井出英一, 西岡映二, 石井利昭, 楠川順平, 中津欣也, 諏 訪時人：特許第 5542765 号

13) Mohammad Anwar, S. M., et al.: "Development of a Power Dense and Environmentally Robust Traction Power Inverter for the Second-Generation Chevrolet VOLT Extended-Range EV," Proc. ECCE 2015, pp. 6006-6013, 2015

14）中沢将剛, 三柳俊之, 岩本 進: “Si-IGBT・SiC-SBD ハイ ブリッドモジュール,”富士時報, Vol. 84, No. 5, pp. 331335,2011
15）高橋義一, 望月英司, 池田良成 : “次世代パワー半導体パッ ケージ・実装技術,” Mate2011 予稿集, pp. 187-192, 2011

16）日立製作所ホームページ，http://www.hitachi.co.jp/New/ cnews/month/2015/09/0928a.html

17) 山口拓人, 東平知丈, 池田 靖, 秦 昌平 : “ $\mathrm{Zn} / \mathrm{Al} / \mathrm{Zn}$ ク ラッド材を用いた高耐熱接合技術, ” Mate2013 予稿集, pp. $27-32,2013$

18）塩見昌平, 丸岡智樹, 菊内康正： “ $\mathrm{Cu}$ ナノ粒子の製作とデ バイス接合技術への展開一 $\mathrm{Cu}$ ナノ粒子の粒径制御技術の確 立一, ”京都市産業技術研究所 研究報告, No. 4, pp. 28-33, 2014

19) "High reliability packaging technologies for $175 \mathrm{deg} . \mathrm{C}$ continuous operation in IGBT module," Proc. of Electronics Packaging and iMAPS All Asia Conference (ICEP-IACC), pp. 791-794, 2015

20) 宮崎高彰, 池田 靖: “パワーモジュール向け $\mathrm{Sn}-\mathrm{Cu}$ 系はん だの高信頼化,”Mate2015 予稿集, pp. 91-96, 2015

21）三宅敏広：“車載エレクトロニクス実装の現状と展望,”エ レクトロニクス実装学会誌, Vol. 13, No. 1, pp. 20-24, 2010.1

22）三宅敏広，猪川幸司，田原啓輔，大竹精一郎，加藤康夫, 河喜多心哉：“カーエレクトロニクス実装の現状と展望, ” エレクトロニクス実装学会誌, Vol. 19, No. 1, pp. 66-71, 2016.1

23) 三宅敏広, 中村直樹, 河喜多心哉, 大竹精一郎, 越地福 朗 : “カーエレクトロニクス実装の現状と展望, ”エレクト ロニクス実装学会誌，Vol. 20, No. 1,pp. 73-77, 2017.1

24）寺田博之: “わかりやすい構造破壊の防止技術,”養賢堂, pp. $43-52,2006$

25）佐藤尚幸, 斎藤 寧, 玉井輝夫, 飯田和生, 伊藤哲也, 服 部康弘：“微摺動摩耗による接触抵抗変化の機構に関する研 究, ”電子情報通信学会技術研究報告信学技報, Vol. 107, No. 484 , pp. $31-36,2008.2$

26) 藤田勝久：“振動工学,” 森北出版, pp. 13-15, 2005

27) S. M. Kumar：“ランダム振動の疲労解析, ”ANSYS Advantage, Vol. II, 3, 2008

28）大竹精一郎：“現状の車載特有の半導体実装技術と将来動 向,”エレクトロニクス実装学会第 31 回春季講演大会

29) 藤井磨永：“車載エンジン環境における $\mathrm{Cu}$ ワイヤボンド技 術パッケージ応力の影響, ”エレクトロニクス実装学会 MES2016

30) 國枝大佳：“車載エンジン環境における $\mathrm{Cu}$ ワイヤボンド技 術樹脂封止中の腐食成分低減,”エレクトロニクス実装学会 MES2016

\section{$\dagger$ 用語解説}

EV (Electric Vehicle)

FCV (Fuel Cell Vehicle)

HV (Hybrid Vehicle) 
IGBT (Insulated Gate Bipolar Transistor)

ECU (Engine Control Unit)

ADAS (Advanced Driving Assistant System)
HEV (Hybrid Electric Vehicle)

ABS (Antilock Brake System)

ETC (Electronic Toll Collection System)

著者紹介

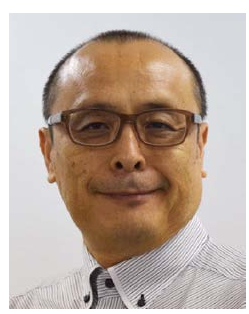

大竹精一郎（おおたけ せいいちろう）

1982 年（株）デンソーに入社。

入社以来, 半導体製品の開発, 設計に従事。

現在，デバイス事業部半導体実装開発部に所属。

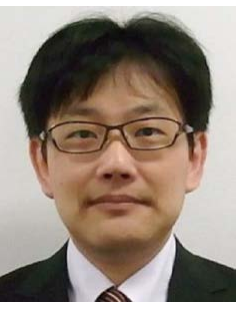

三田夏大（みた なつひろ）

2005 年イリソ電子工業株式会社に入社。

現在，技術本部開発部に所属。

コネク夕の要素技術開発, 振動疲労㧍よび熱疲労 の評価，解析技術などに従事。

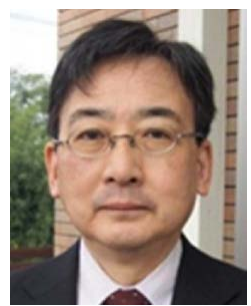

三宅敏広（みやけ としひろ）

1985 年岐皁大学大学院工学研究科修士課程修了, 1991 年株式会社デンソー入社, プリント配線板お よび接続技術開発に従事，2009 年岐阜大学大学院 工学研究科博士後期課程物質工学専攻修了, 博士 (工学），現在 基盤ハードウェア開発部にて車載 メカトロニクス実装技術開発に従事，JIEP 常任理 事。

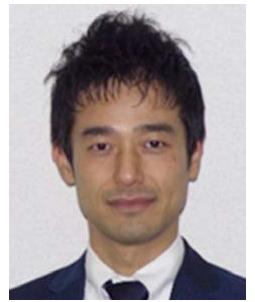

河喜多心哉（かわきた しんや）

2003 年（株）日立製作所入社。現在，研究開発グ ループ生産イノベーションセンタ所属。

2004 年から車載電子機器の放熱性，信頼性に関す 了研究に従事。

エレクトロニクス実装学会会員, 日本機械学会会 員。

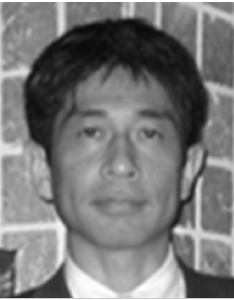

長谷川清久（はせがわ きよひさ）

1986 年イビデン株式会社に入社。COB 設計, パッ ケージ/ボード設計，社内CAD/CAM 開発。1994 年イビテック株式会社に転籍し、シミュレーショ ン技術開発，SiP/Si-IP／モジュール設計に従事。 2013 年株式会社図研に入社。3D 積層 IC / 部品内 蔵/3D-MID などの設計環境構築・ッール開発業 務に従事。エレクトロニクス実装学会 ミッショ ンフェロー副查，回路・実装設計技術委員会副幹 事, 部品内蔵技術委員会委員, カーエレクトロニ クス研究会幹事。 